\title{
Intraoperative autologous blood transfusion: report of a technique
}

\author{
R A H E E M M A . K H A N \\ and HAROLD F. M. BASSET T \\ Department of Cardiothoracic Surgery, Manchester Royal Infirmary
}

\begin{abstract}
Khan, R. M. A. and Bassett, H. F. M. (1975). Thorax, 30, 447-451. Intraoperative autologous blood transfusion: report of a technique. Using a simple and relatively inexpensive technique, blood was salvaged during major thoracic and cardiovascular surgery in 34 cases. Detailed haematological, biochemical, and bacteriological studies were carried out, with red cell survival studies. It has been shown that cellular as well as non-cellular elements of the blood were well preserved with little or no bacterial contamination. It has been suggested that this form of autologous blood is a more suitable form of blood replacement than donor blood.
\end{abstract}

There is an ever increasing demand on the blood transfusion services for blood and its constituents. With improved techniques in serology, new and rare antigens and antibodies are being recognized. These present some real problems with regard to the blood donors. There are parts of the world where organization of blood transfusion services is inadequate. The hazards of blood transfusion using stored donor blood are well recognized. Furthermore, there may be theological objections to the use of donor blood.

Autotransfusion as a method of blood replacement was first suggested by Highmore about 100 years ago. It has been used increasingly in obstetrics (Butler, 1929; Maynard and Rees, 1929; Ricci and Di Palma, 1931; Tiber, 1934) and in surgery, including open-heart surgery (Wagstaffe, Clarke, and Jackson, 1972).

In most instances blood used for replacement was collected from the patients concerned several days before operation (Boerema and Fierstra, 1955; Cuello et al., 1967; Daggett et al., 1970). The blood lost during operative procedures was presumably discarded. It was not until the Vietnam war that Klebanoff (1970), using an apparatus for simultaneous aspiration, filtration, and reinfusion of the blood lost at operation, was able to operate on serious battle injuries and other emergencies. There are many parts of the world where indications for this form of blood replacement exist even during peace time.

Ideally, the technique for intraoperative auto- logous blood replacement should be safe, simple, and relatively inexpensive. A technique of salvaging blood during major thoracic and cardiovascular surgical procedures is described.

\section{METHODS AND MATERIAL}

Preliminary studies were carried out on 12 adults, four men and eight women (group 1). A standard suction system was used with high vacuum (up to $-100 \mathrm{mmHg}$ ). The suction nozzles used were narrow with small areas of entry near their tips. Blood from the site of operation was collected in autoclaved transfusion bottles, each containing 1500 units of heparin.

Equipment and technique have evolved with experience. Joints are avoided, and the tubing itself is wide in diameter and short in length. For the present improved technique, which has been used in 22 adults, four men and 18 women (group 2), the following equipment is required: two lengths of plastic tubing, each approximately $45 \mathrm{~cm}$ long, with an internal diameter of 7 or $8 \mathrm{~mm}$; a supply of standard transfusion bottles, each containing $100 \mathrm{ml}$ of standard acid-citrate-dextrose (ACD) solution; a rubber bung with two holes, one large and one small, and a metal cannula.

This equipment is assembled by inserting the bung with the holes into the transfusion bottles. Two large side holes are cut out near the tip of one of the pieces of tubing, which is then used as the suction nozzle; its other end is introduced 
through the larger hole of the bung. The other tube is connected to the metal cannula which is introduced through the smaller hole of the bung. This tube is connected to an adjustable suction unit set at -3 to $-5 \mathrm{mmHg}$ and shifting two litres of air per minute. The assembled unit (Fig. 1) is anchored to the drapes close to the site of operation.

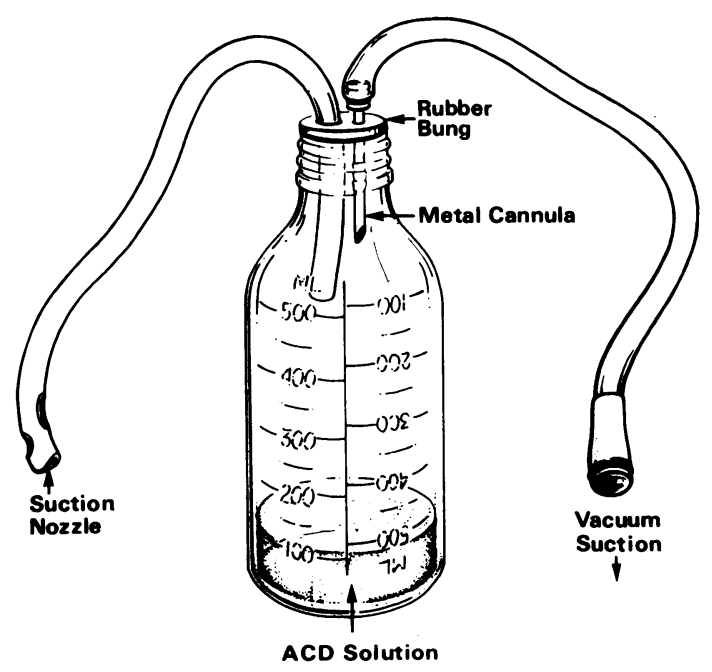

FIG. 1. The assembled unit for the salvage of autologous blood used in group 2 patients.

After opening the chest, $0.5-1 \mathrm{mg} / \mathrm{kg}$ body weight of heparin is given intravenously. This dose may have to be repeated at hourly intervals if the operation is long. The operative field is cleared of any blood clots, using high pressure 'discard' suction, before starting the process of salvaging the blood. The suction nozzle is now placed in an area where most of the blood is likely to collect. From time to time the bottle is shaken gently to allow mixing of the blood with ACD solution. Once the bottle is full, the rubber bung with tubes in situ is transferred to the next bottle and the process of blood collection is continued.

In case of sudden loss of a large volume of blood, suction can be increased up to $-5 \mathrm{mmHg}$ and later turned down to $-3 \mathrm{mmHg}$ as soon as possible. Whenever a potentially infected organ, such as the oesophagus or bronchus is opened, the process of blood collection is discontinued. The suction is turned off when there is evidence of adequate haemostasis.

The use of swabs is avoided as far as possible.
High pressure 'discard' suction is used very sparingly. No protamine is given at the end of the operation as it has been found to be unnecessary with the dosage of heparin used. The salvaged blood is now run through an ordinary blood giving set with its own filtration chamber. The last few millilitres of blood are discarded to avoid fat particles.

In this study samples of filtered blood were taken for detailed haematological studies-morphological appearances of the film, alteration in red and white cells, and presence or absence of clots, foreign tissue or material. Free haemoglobin and fibrinogen were estimated and platelets were counted. Red cell survival studies were carried out by labelling them with ${ }^{51} \mathrm{Cr}$ in 12 randomly selected cases, using a technique described by Garby and Mollison (1971). Potassium $\left(\mathrm{K}^{+}\right)$was estimated in the plasma of the salvaged blood and compared with preoperative levels. Further $5 \mathrm{ml}$ samples of blood were taken into blood-culture bottles, one with a Castenada-type medium, the other containing thioglycolate broth to estimate bacterial contamination.

\section{RESULTS}

The results of preliminary high vacuum studies of group 1 are shown in Table I. Only $27 \%$ of the blood was salvaged and the rest was discarded, mainly in the form of clots. There were fine clots present even in the salvaged blood, with evidence of excessive destruction of cellular as well as non cellular elements of blood. $\mathrm{K}^{+}$in the salvaged blood (mean $4.9 \mathrm{mmol} / \mathrm{l}$ ) was higher than preoperative levels (mean $4.0 \mathrm{mmol} / \mathrm{l}$ ). Free plasma haemoglobin was high (mean $535 \mathrm{mg} / \mathrm{dl}$ ). Platelets and fibrinogen were very poorly preserved.

Table II shows the results of the present technique using the changes brought in since the pre- $\frac{\text { 일 }}{2}$ liminary studies, including the use of systemic $D$ heparin. The blood salvaged was $77 \%$ of the operative losses. In 14 out of 22 cases $(64 \%)$ the $N$ blood discarded was less than $100 \mathrm{ml}$. The red and white cells were well preserved with no evidence

T A B L E I

DETAILS OF PRELIMINARY STUDIES USING STANDARD HIGH VACUUM SUCTION IN 12 PATIENTS (GROUP 1)

\begin{tabular}{l|c|c|c|c|c}
\hline & $\begin{array}{c}\text { Age } \\
(\mathrm{yr})\end{array}$ & $\begin{array}{c}\text { Blood } \\
\text { Salvaged } \\
\%\end{array}$ & $\begin{array}{c}\text { Platelets } \\
/ \mathrm{mm}^{3}\end{array}$ & $\begin{array}{c}\text { Fibrinogen } \\
(\mathrm{mg} / \mathrm{dl})\end{array}$ & $\begin{array}{c}\text { Plasma Hb } \\
(\mathrm{mg} / \mathrm{dl})\end{array}$ \\
\hline $\begin{array}{l}\text { Range } \\
\text { Mean } \\
\pm \mathrm{SE}\end{array}$ & $\begin{array}{c}43-64 \\
52\end{array}$ & $\begin{array}{c}19-38 \\
27\end{array}$ & $<10000$ & $\begin{array}{c}<50-136 \\
70\end{array}$ & $\begin{array}{c}240-696 \\
535 \\
11 \cdot 7\end{array}$ \\
\hline
\end{tabular}

$\mathrm{SE}=$ standard error. 
T A B L E I I

DETAILS OF CASES STUDIED IN GROUP 2

\begin{tabular}{|c|c|c|c|c|c|c|c|c|}
\hline \multirow[b]{2}{*}{$\begin{array}{l}\text { Case } \\
\text { No. }\end{array}$} & \multirow[b]{2}{*}{$\begin{array}{l}\text { Age } \\
(y r)\end{array}$} & \multirow[b]{2}{*}{ Sex } & \multicolumn{2}{|c|}{ Operative Blood Loss } & \multirow{2}{*}{$\begin{array}{c}\text { Blood } \\
\text { Salvaged } \\
\%\end{array}$} & \multirow[b]{2}{*}{$\begin{array}{l}\text { Platelets } \\
/ \mathrm{mm}^{3}\end{array}$} & \multirow[b]{2}{*}{$\begin{array}{l}\text { Fibrinogen } \\
\text { (mg/dl) }\end{array}$} & \multirow[b]{2}{*}{$\underset{(\mathrm{mg} / \mathrm{dl})}{\text { Plasma Hb }}$} \\
\hline & & & $\begin{array}{c}\text { Discarded } \\
\text { (ml) }\end{array}$ & $\begin{array}{l}\text { Salvaged } \\
\text { (ml) }\end{array}$ & & & & \\
\hline $\begin{array}{l}1 \\
2 \\
3 \\
4 \\
5 \\
6 \\
7 \\
8 \\
9 \\
10 \\
11 \\
12 \\
13 \\
14 \\
15 \\
16 \\
17 \\
18 \\
19 \\
20 \\
21 \\
22 \\
\text { Range } \\
\text { Mean } \\
\pm \text { SE }\end{array}$ & $\begin{array}{c}43 \\
53 \\
40 \\
69 \\
37 \\
35 \\
59 \\
54 \\
52 \\
40 \\
50 \\
56 \\
59 \\
45 \\
54 \\
37 \\
53 \\
30 \\
42 \\
51 \\
61 \\
53 \\
30-61 \\
49 \\
-\end{array}$ & $\begin{array}{l}\mathbf{F} \\
\mathbf{F} \\
\mathbf{F} \\
\mathbf{F} \\
\mathbf{F} \\
\mathbf{F} \\
\mathbf{F} \\
\mathbf{F} \\
\mathbf{F} \\
\mathbf{F} \\
\mathbf{F} \\
\mathbf{F} \\
\mathbf{M} \\
\mathbf{F} \\
\mathbf{F} \\
\mathbf{M} \\
\mathbf{F} \\
\mathbf{M} \\
\mathbf{F} \\
\mathbf{F} \\
\mathbf{F} \\
- \\
\end{array}$ & $\begin{array}{r}<100 \\
<100 \\
300 \\
350 \\
<100 \\
250 \\
<100 \\
200 \\
400 \\
200 \\
200 \\
<100 \\
<100 \\
<100 \\
<100 \\
<100 \\
<100 \\
<100 \\
<100 \\
<100 \\
350 \\
<100 \\
- \\
- \\
-\end{array}$ & $\begin{array}{r}300 \\
450 \\
600 \\
750 \\
450 \\
1100 \\
350 \\
800 \\
450 \\
1300 \\
700 \\
450 \\
400 \\
320 \\
350 \\
300 \\
1000 \\
200 \\
350 \\
450 \\
700 \\
200 \\
- \\
- \\
-\end{array}$ & $\begin{array}{c}75 \\
82 \\
67 \\
68 \\
82 \\
81 \\
78 \\
80 \\
82 \\
87 \\
78 \\
82 \\
75 \\
77 \\
78 \\
75 \\
90 \\
67 \\
78 \\
82 \\
67 \\
67 \\
67-90 \\
77 \\
1.4\end{array}$ & $\begin{array}{c}3 \overline{3} 000 \\
75000 \\
\overline{36000} \\
102000 \\
77000 \\
50000 \\
50000 \\
61000 \\
55000 \\
91000 \\
85000 \\
70000 \\
94000 \\
50000 \\
124000 \\
63000 \\
86000 \\
81000 \\
108000 \\
57000 \\
39000-124000 \\
73000 \\
5 \cdot 2\end{array}$ & $\begin{array}{c}141 \\
328 \\
<50 \\
139 \\
230 \\
103 \\
- \\
135 \\
207 \\
366 \\
158 \\
211 \\
<50 \\
158 \\
204 \\
132 \\
215 \\
246 \\
186 \\
66 \\
<50-366 \\
174 \\
1.9\end{array}$ & $\begin{array}{l}\overline{53} \\
292 \\
260 \\
158 \\
56 \\
175 \\
41 \\
\overline{53} \\
220 \\
218 \\
178 \\
188 \\
107 \\
92 \\
90 \\
40 \\
215 \\
270 \\
225 \\
252 \\
40-292 \\
159 \\
18 \cdot 9\end{array}$ \\
\hline
\end{tabular}

$\mathbf{S E}=$ standard error.

of clots in the film. Red cells haemolysis was reduced, thus reducing the plasma haemoglobin (mean $159 \mathrm{mg} / \mathrm{dl}$ ) as well as $\mathrm{K}^{+}$(mean $3.4 \mathrm{mmol} / \mathrm{l}$ ), which was very little different from preoperative levels (mean $3.9 \mathrm{mmol} / \mathrm{l}$ ). In eight out of 19 cases $(42 \%)$ the fibrinogen was found to be within normal limits (mean $174 \mathrm{mg} / \mathrm{dl}$ ). The platelets were also relatively well preserved (mean $73000 / \mathrm{mm}^{3}$ ).

Bacteriological cultures produced no growth on initial or serial subcultures in seven out of 22 cases $(32 \%)$. Although in the remaining 15 cases $(68 \%)$ contaminants were grown in only one of the two media used on initial culture, serial subcultures of these media produced no additional organisms. The organisms which were found were diphtheroids and Staphylococcus albus and almost certainly represented contamination during subsequent handling of the samples.

The red cell survival studies showed that the mean half life $\left(\mathrm{T}_{50}\right)$ of the salvaged red cells was 21 days (range 15-33). This compares favourably with the $T_{50}$ of normal, fresh red cells (mean 30 days, range 25-33) as shown by Garby and Mollison (1971).

\section{DISCUSSION}

Although autotransfusion as a method of blood replacement has been practised on innumerable occasions in the past, there are very few reports in the literature where blood lost during operative procedures has been salvaged and reinfused (Dyer,
1966; Wilson and Taswell, 1968; Klebanoff, 1970).

During preliminary studies in group 1 patients it became obvious that only $27 \%$ of the operative loss was being salvaged and that this was unsuitable for reinfusion. At this stage it was decided reluctantly to use systemic heparin. However, its use has not made any appreciable difference to the intra and postoperative blood losses; with its use it was possible to salvage up to $90 \%$ of the operative blood loss. The discard of less than $100 \mathrm{ml}$ of blood in the presence of large or small operative loss was fairly constant, as observed in 14 out of 22 cases $(64 \%)$.

Excessive trauma to various elements of blood, observed in group 1 patients, was reduced by lowering the negative pressure of the suction, by bringing the whole unit close to the site of operation and thus reducing the length of tubing, by avoiding unnecessary metal connections, and by using wide bore suction nozzles with larger side holes to allow larger areas of entry. Similar observations were made by Osborn et al. (1962). The use of roller pumps has been avoided since it has been shown that their use increases red cell haemolysis (Benzing, De Forest, and Kaplan, 1966).

This form of blood replacement has many advantages. A patient's own blood is the only truly compatible blood and strain on the transfusion services is reduced as no grouping and crossmatching is required. 
A distinct advantage of autologous blood is the availability of well preserved platelets and fibrinogen; indeed there is some indication that when blood losses are greater the platelets and fibrinogen may be preserved more efficiently. When there is a large loss and replacement, abundance or deficiency of these essential factors could be crucial. Wagstaffe et al. (1972) have shown that by using fresh autologous blood after cardiopulmonary bypass and restoring the platelet level they have been able to reduce postoperative blood loss.

It is obvious from the results that serious bacteriological infection can be avoided since the organisms were isolated from only one of the two media used and no further growth was obtained on serial subcultures. It is quite probable that this was contamination introduced during the postoperative studies. This impression has been further substantiated by the results in 16 cases investigated after the conclusion of this preliminary study, as all clinical, haematological, and bacteriological studies have consistently shown no evidence of infection following the reinfusion of intraoperatively salvaged blood.

Up to $90 \%$ of the operative loss can be salvaged with minimal trauma to the blood and little or no bacterial contamination and reinfused to the patient. Efforts are being made to improve the technique further, including the use of a prototype autologous blood salvage unit. The two

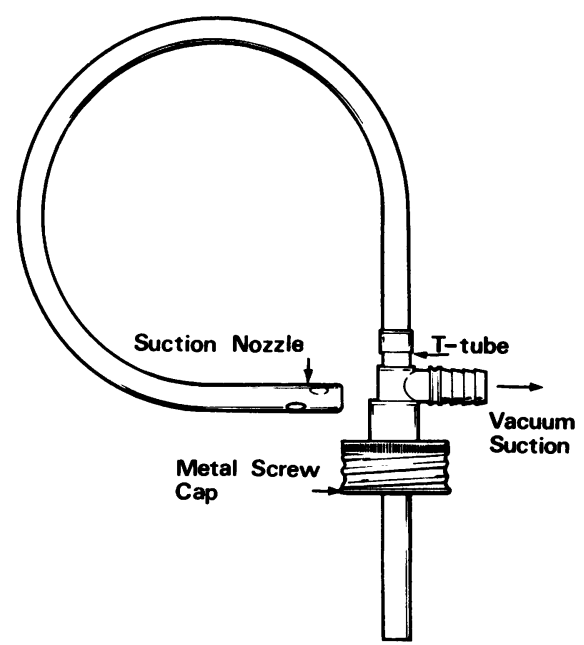

FIG. 2. This shows the new prototype blood salvage unit. essential aims of this method continue to be $\overrightarrow{\overline{\vec{s}}}$ simplicity and low cost.

We wish to thank Mr. Kenneth Bloor for allowing us to study the cases under his care, Dr. J. A. Tooth for assessment of bacteriological contamination, Miss Mulrayn and Miss Bottomley for their help with thehaematological studies, the Department of Medical ${ }^{\circ}$ Illustration for Fig. 1, Mrs. Vera Thornton and Mrs. $\vec{\omega}$ P. Dalby for secretarial assistance, and lastly-but noto the least-the nursing staff of the Cardiac Surgery Unit for their hard work.

\section{REFERENCES}

Benzing, G., De Forest, D., and Kaplan, S. (1966). Multiple-line single-reservoir automatic cardio-음 tomy blood return system. Journal of Thoracic and Cardiovascular Surgery, 51, 238.

Boerema, I. and Fierstra, A. A. (1955). Preoperative venesection (for later transfusion). Nederlands $\frac{c}{\omega}$ Tijdschrift voor Geneeskunde, 99, 69.

Butler, H. B. (1929). Auto-blood-transfusion in two cases of ruptured tubal pregnancy. British Medi-o cal Journal, 2, 1006.

Cuello, L., Vázquez, E., Pérez, V., and Raffucci, F. L. (1967). Autologous blood transfusion in cardiovascular surgery. Transfusion, 7, 309.

Daggett, W. M., Gada, P. H., Leape, L. L., Scannell, 응 J. G., and Tartakoff, J. (1970). Autologous blood transfusion in pulmonary surgery. Journal of $\overrightarrow{\vec{B}}$ Thoracic and Cardiovascular Surgery, 59, 546.

Dyer, R. H. Jnr (1966). Intraoperative autotrans- $\frac{-}{J}$ fusion: A preliminary report and new method. American Journal of Surgery, 112, 874.

Garby, L. and Mollison, P. L. (1971). Deduction of mean red-cell life-span from ${ }^{51} \mathrm{Cr}$ survival curves. British Journal of Haematology, 20, 527.

Highmore, W. (1874). Overlooked source of blood-음 supply for transfusion in post-partum haemorr hage. Lancet, 1, 89.

Klebanoff, G. (1970). Early clinical experience with a disposable unit for the intraoperative salvage and reinfusion of blood loss (intraoperative auto- $工$ transfusion). American Journal of Surgery, 120, 718.

Maynard, R. L. and Rees, W. T. (1929). A case of $N$ ruptured extra-uterine pregnancy treated by. autofusion. Journal of American Medical Association, 92, 1758.

Osborn, J. J., Cohn, K., Hait, M., Russi, M., Salel, A., Harkins, G., and Gerbode, F. (1962). Hemolysis during perfusion. Sources and meanso of reduction. Journal of Thoracic and Cardio- $\bar{\oplus}$ vascular Surgery, 43, 459.

Ricci, J. V. and Di Palma, S. (1931). Analysis of 1007 cases of ruptured ectopic gestation: technic and evaluation of autohemofusion. American Journal $\overparen{\mathbb{D}}$ of Obstetrics and Gynaecology, 22, 857.

Tiber, L. J. (1934). Ruptured ectopic pregnancy. California and Western Medicine, 41, 16.

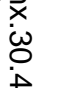


Wagstaffe, J. G., Clarke, A. D., and Jackson, P. W. (1972). Reduction of blood loss by restoration of platelet levels using fresh autologous blood after cardiopulmonary bypass. Thorax, 27, 410.

Wilson, J. D. and Taswell, H. F. (1968). Autotransfusion: historical review and preliminary report on a new method. Mayo Clinic Proceedings, 43, 26.

\section{ADDENDUM}

Charles F. Thackray Ltd. have produced a relatively inexpensive autologous intraoperative blood salvage unit to our specifications. Figure 2 shows the assembled unit which consists of a metal screw cap, incorporating a rubber bung with a large central hole for one limb of a $T$ tube and a length of tubing as before which is introduced through the horizontal limb of the $T$ tube. The other end of the tubing is used as a suction nozzle. There are no joints or interruptions in the tubing.

Requests for reprints to: Mrs. Vera Thornton, S 5 Unit Medical Records, Manchester Royal Infirmary, Oxford Road, Manchester. 